\title{
HOLOCENE FOREST HISTORY OF THE PÖYRISJÄRVI AREA NORTH OF THE CONIFEROUS TREE LINE IN WESTERN FINNISH LAPLAND: A POLLEN STRATIGRAPHICAL STUDY
}

\author{
EEVA MÄKELÄ, KAARINA SARMAJA-KORJONEN \\ and HANNU HYVÄRINEN
}

MÄKELÄ, EEVA; SARMAJA-KORJONEN, KAARINA and HYVÄRINEN, HANNU 1994. Holocene forest history of the Pöyrisjärvi area north of the coniferous tree line in western Finnish Lapland: a pollen stratigraphical study. Bull. Geol. Soc. Finland 66, Part 2, 81-94.

The evolution of the forests beyond the current coniferous tree line during the Holocene was studied by means of pollen analysis. Two closed-basin lakes, Jierstivaara and Isohattu, in western Finnish Lapland, were cored for the purpose. The rate of sedimentation proved to be uneven. After a slow initial rate a marked acceleration occurs between 6000 and $4000 \mathrm{BP}$. The last three millenia seem to have been a period of even sedimentation. A stage of raised pollen concentrations coincides with the accelerating rates of sediment growth. Fluctuations in the water table of the lakes are estimated to have contributed to the changes in the matrix sedimentation and in the pollen concentration. Pine arrived in the area 6000-6500 BP. Pure pine forest was never established. During the last 3000 years pine has almost totally disappeared from the vicinity of the sites.

From the Jierstivaara core additional close-interval pollen and charcoal analyses were made which cover a period from about 8200 to 4500 BP. They show in more detail the spread of pine and the following time of low water lever which coincides with a period of high juniper values for about 600 radiocarbon years. Low charcoal values throughout the sequence point to a minor role of fires in the area.

Key words: pollen analysis, tree line, forest history, pollen deposition rates, Holocene, northern Fennoscandia, charcoal analysis, forest fires.

Eeva Mäkelä, Kaarina Sarmaja-Korjonen, and Hannu Hyvärinen: Department of Geology, Division of Geology and Palaeontology, University of Helsinki, P.O. Box 11, FIN-00014 University of Helsinki, Finland. 


\section{THE STUDY AREA AND DESCRIPTION OF THE SITES}

Figs 1 and 2 depict the location of the study area and the sites in western Finnish Lapland. The deglaciation of the area occurred in the early Holocene between 9000 and 10000 BP (Kujansuu 1967, Hyvärinen 1973). As shown in Fig. 1 the area lies beyond the present limit of pine. Today the nearest pine woods are situated $20-30 \mathrm{~km}$ to the south. Numerous finds of subfossil pine trunks in small lakes indicate a more northerly existence of pine woodland in the past, however.

The landscape is dominated by the bedrock hills, Termisvaara (610 $\mathrm{m}$ a.s.1.) and Jierstivaara (647 m a.s.1.), covered by a thin and patchy mantle of till.
The bedrock consists of granite excluding a strip of amphibolites between Jierstivaara and Termisvaara. Glaciofluvial gravels and eolian sands cover the northern and western flanks of Jierstivaara. An esker train runs across the area from northeast to southwest. There are many small closed basin lakes filling the depressions in the glaciofluvial material. As such they are easily affected by changes in the ground water table.

Thin mountain birch (Betula pubescens subsp. tortuosa) woodland spreads over most of the area. Some solitary pines trees rise above the prevailing shrubby vegetation. Wet depressions and lake shores are extensively paludified. Above the local altitudinal birch limit at 450-480 m the hill slopes are covered with dwarf-shrub heath. In places above

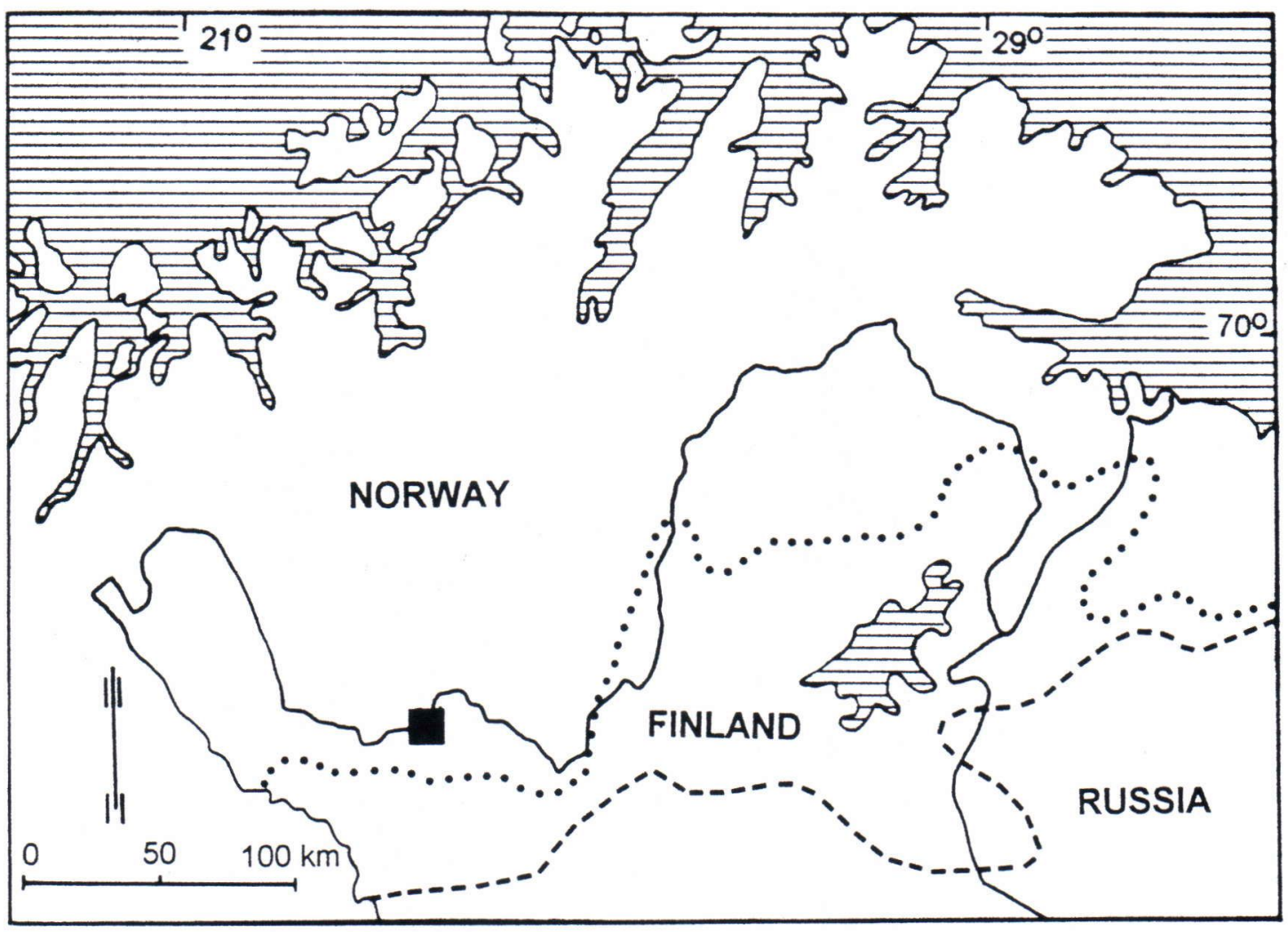

Fig. 1. Location of the study area (black square) in western Finnish Lapland. The dotted line indicates the northern limit of continuous occurrence of pine, the dashed line the northern limit of spruce. 


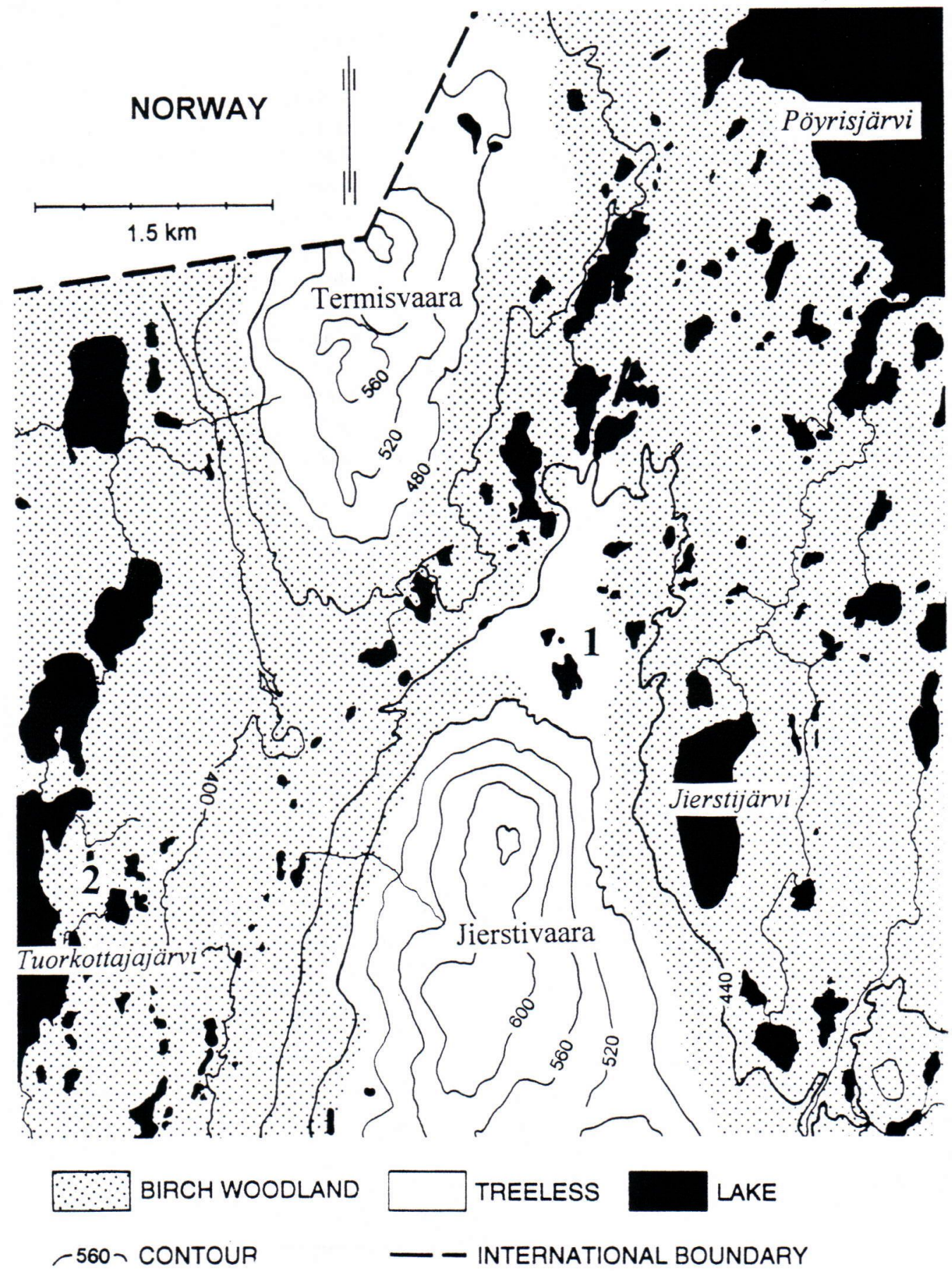

Fig. 2. A close-up of the study area in the commune of Enontekiö near lake Pöyrisjärvi. The sites studied are: 1 Jierstivaara, 2. Isohattu. 
the birch limit bare rock is exposed and barren rock fields are a characteristic feature of the landscape.

Both of the lakes studied have relatively shallow and flat-bottomed basins in glaciofluvial material. The first site, Jierstivaara $456 \mathrm{~m}$ a.s.l. (number 1. in Fig. 2), lies near the upper limit of birch on the northern slope of Jierstivaara. The other site, Isohattu 386 ma.s.1. (number 2 in Fig. 2), is surrounded by birch woodland. Lake Jierstivaara has no outlets whereas Isohattu drains through a small brook flowing to the west towards Lake Tuorkottajärvi. The lakes have similar surface areas between 6 and 7 ha.

The lakes were cored from the ice in April 1991. The samples were taken approximately from the centre of the lakes using a piston corer. Water depths at the sampling spots were $2.5 \mathrm{~m}$ (Jierstivaara) and $3 \mathrm{~m}$ (Isohattu) and the cores obtained $320 \mathrm{~cm}$ and $240 \mathrm{~cm}$ long respectively.

\section{METHODS}

Water content and loss-on-ignition were measured from both cores at $20 \mathrm{~cm}$ intervals. As the ignition residue proved out to be rich in diatoms the Jierstivaara core was analysed for the content of biogenic silica using a method desrcibed by Enell \& Larsson (1985). In short, the method includes the dissolving of biogenic silica and determining the dissolved silica with a spectrophotometer by the molybdene-blue method under reducing conditions. The results are displayed in Fig. 3.

The pollen samples were processed and analysed by standard methods (Faegri \& Iversen 1989). The cores was sampled at $5 \mathrm{~cm}$ intervals. Samples of 0.5 $\mathrm{cm}^{3}$ were used. The lowermost samples containing mineral matter went through a HF-treatment, $320-300 \mathrm{~cm}$ in the Jierstivaara core and 236-228.5 $\mathrm{cm}$ in the Isohattu core. Other samples were treated with potassium hydroxide $(\mathrm{KOH})$ only. Before the actual treatment two Lycopodium-spore tablets, à 12100 spores, were added for the calculation of pollen concentrations per unit volume (Stockmarr 1971). The samples were mounted in glycerol stained with safranin. Counting the pollen, the aim was to get ca. 500 upland pollen grains with at least 200 added Lycopodium-spores.

For further elucidation of the changes in pollen deposition and vegetation during the spread of pine, close-interval pollen and charcoal analyses were made from the Jierstivaara core. The section between 220-300 cm was sampled contiguously with samples covering $1 \mathrm{~cm}$. The eight lowermost samples were treated with the $\mathrm{KOH}, \mathrm{HF}$ and acetolysis methods (Faegri \& Iversen 1989) and the other samples only with the $\mathrm{KOH}$ method. Two Lycopodium tablets (à 13911 spores) were added to measure the concentrations. Charcoal particles were counted both by numbers and by surface area with the method decribed in Sarmaja-Korjonen (1992). Only the concentration of charcoal particles is presented.

\section{RESULTS}

\section{Sediment stratigraphy, dating and rates of sedimentation}

The stratigraphy columns and the rates of sedimentation are illustrated in Fig. 3. The sediment stratigraphy in the cores begins with basal sands and sandy silts overlain by a thin layer of compact silty gyttja and gyttja. The gyttja grades into dark brown coarse detritus mud (dy) with varying amounts of moss remains. In Jierstivaara core the lower part of detritus mud is especially rich in moss remains, mostly sphagna.

The loss-on-ignition values fluctuate but no consistent change occurs after the initial rise. In Jierstivaara core the organic content curve is further smoothed by the addition of biogenic silica to the loss-on-ignition values.

The Dating Laboratory of the University of Helsinki carried out the radiocarbon dating (Table 1). Eleven dates were obtained; 6 for the Jierstivaara series and 5 for the Isohattu series. The samples for dating were taken at even intervals from the Isohattu core. In the Jierstivaara core an additional sample was dated from the lower part where the 
JIERSTIVAARA, Enontekiö

$68^{\circ} 40^{\prime} \mathrm{N}, 23^{\circ} 44^{\prime} \mathrm{E} ; 456 \mathrm{~m}$

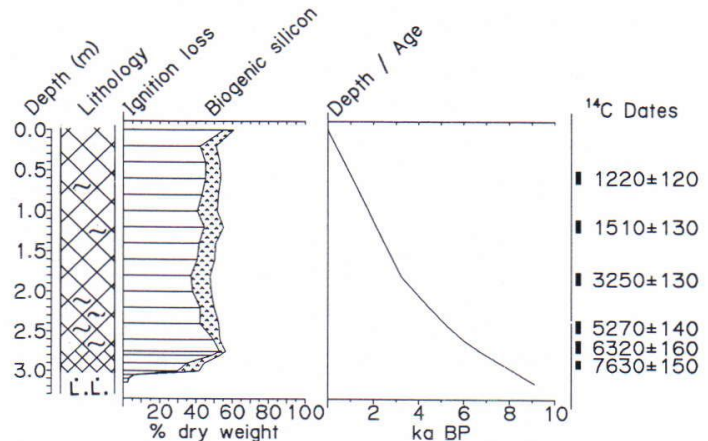

ISOHATTU, Enontekiö

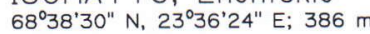

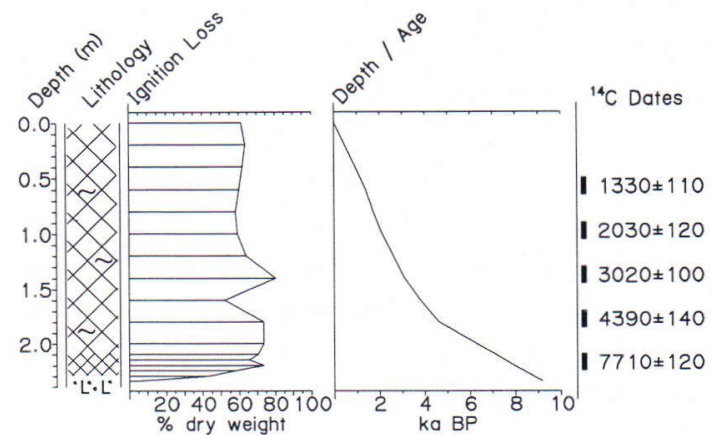

Fig. 3. Lithology, radiocarbon dates and interpolated sedimentation curves for Jierstivaara and Isohattu. Sediment symbols from below: sandy silt, compact greenish brown silty gyttja and gyttja, dark brown detritus mud (dy) with moss remains. The basal layer in both the cores consisted of sandy and gravelly material. In the Jierstivaara curves the LOI and biogenic silica percentages are combined to show the total organic content in the sediment.

\section{Site}

Jierstivaara

Isohattu

\section{Sample depth Lab. No $\delta^{13} \mathrm{C}$ ( cm)}

$50-65$

$110-125$

$175-190$

$235-250$

$260-275$

$285-295$

$50-65$

$90-105$

$130-145$

$170-185$

$210-225$

$\begin{array}{lll}\text { Hel-3167 } & -25.3 & 1220 \pm 120 \\ \text { Hel-3166 } & -26.3 & 1510 \pm 130 \\ \text { Hel-3165 } & -26.9 & 3250 \pm 130 \\ \text { Hel-3164 } & -28.9 & 5270 \pm 140 \\ \text { Hel-3163 } & -28.2 & 6320 \pm 160 \\ \text { Hel-3162 } & -23.6 & 7630 \pm 150 \\ \text { Hel-3237 } & -27.2 & 1330 \pm 110 \\ \text { Hel-3238 } & -27.6 & 2030 \pm 120 \\ \text { Hel-3239 } & -28.7 & 3020 \pm 100 \\ \text { Hel-3240 } & -25.5 & 4390 \pm 140 \\ \text { Hel-3241 } & -25.4 & 7710 \pm 120\end{array}$

Age BP 
deposition seemed to have been slow according to pollen stratigraphy (see Fig. 3). The radiocarbon ages used here are uncalibrated radiocarbon years.

The dates from the two lakes are consistent and compatible with the overall pollen stratigraphy. The lowermost dates are also in general agreement with Kujansuu's (1967) estimates of deglaciation in the area. The two uppermost dates in Jierstivaara series (HEL-3166 and HEL-3167) are very nearly the same. If both were considered accurate estimates of sediment age they would imply an improbably high rate of sediment growth for the section between them. So, despite the date HEL-3166 an even rate of sedimentation was assumed for the upper part of the Jierstivaara core.

The rate of deposition proved to be very slow in the beginning of the history of the lakes until about 5000 BP. After the slow stage the sedimentation accelerates and remains constantly high. The last three millennia seem to have been a period of even deposition. The rates of sedimentation at their slowest vary between 0.1 and $0.3 \mathrm{~mm} / \mathrm{yr}$ while the highest rates in the upper part of the cores are $0.5-0.6 \mathrm{~mm} / \mathrm{yr}$.

\section{Pollen stratigraphy}

The pollen stratigraphy in Northern Fennoscandia is divided in three regional pollen assemblage zones (Hyvärinen, 1978, 1993). The lowermost section in the pollen diagrams is dominated by birch. The birch stage can be further subdivided in an early phase with occurrence of herbs and Ericales and a later one characterized by ferns and Lycopodium. The basal birch phase represents an initial open vegetation before the establishment of birch forests. It may be preceded by an Artemisia zone where the deglaciation has occurred early. The birch stage comes to an end between 8000 and $7000 \mathrm{BP}$, depending on the area, and is succeeded by a pine-alder stage which terminates approximately $3000 \mathrm{BP}$ with the beginning of a continuous spruce curve.

The diagrams were divided into three local pollen assemblage zones.
Jierstivaara (Figs. 4 and 5):

JIE 1 (ca. 9000-6000 BP). The zone corresponds to the birch phase in the regional stratigraphy. In the beginning of the zone the NAP percentage decreases with the gradual rise of Betula. Equisetum, Lycopodium, Polypodiaceae and Salix reach their maxima. The subdivision into JIE- $1 \mathrm{a}$ and JIE- $1 \mathrm{~b}$ is based on the behavior of Juniperus, Alnus and Isoëtes. The boundary of the two subzones is marked by the appearance of Juniperus and Alnus in the pollen record and a distinct rise in Isoëtes. The upper boundary of the zone is defined by the decline of Juniperus, Polypodiaceae and Lycopodium. Towards the zone JIE-2 boundary Pinus starts to approach its maximum values.

JIE 2 (ca. 6000-3000 BP). The zone corresponds to the pine-alder stage in the regional vegetation history. At the onset of this zone there is a sharp, transient fall in the Betula concentrations. Contemporaneously the peak of Juniperus comes to an end. In the middle of the zone $(220 \mathrm{~cm})$ Isoëtes proportions and concentrations reach a level which remains relatively stable throughout the rest of the diagrams. The start of a continuous Picea curve and the reappearance of Juniperus mark the end of the zone.

JIE 3 (ca. 3000 BP- present). The zone corresponds to the pine-spruce stage. The beginning of the Picea pollen curve reflects the arrival of spruce to its northern limit about $50 \mathrm{~km}$ south of the present area. There are only minor fluctuations in the pollen curves during this zone. The concentrations, mainly those of pine and birch, show a clear drop in the beginning of the zone.

\section{Isohattu (Figs 6 and 7):}

The ages of the pollen assemblage zones as well as the criteria used in distinguishing the zones are very similar to those in the Jierstivaara core.

IH 1 (ca. 9000-6000 BP). The zone corresponds to the birch stage in the regional vegetation history. The immediate rise of the Betula concentration curve together with the low NAP values suggests 


\section{JIERSTIVAARA, Enontekiö}

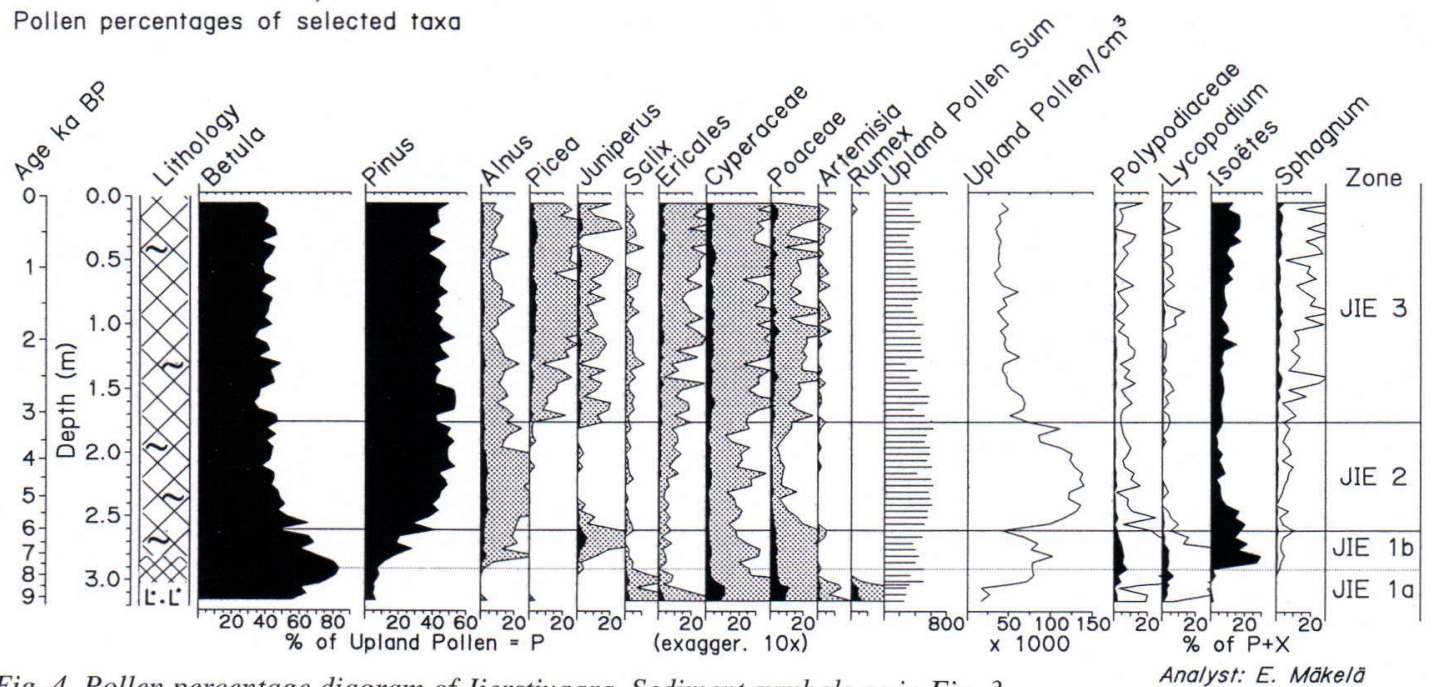

Fig. 4. Pollen percentage diagram of Jierstivaara. Sediment symbols as in Fig. 3.

\section{JIERSTIVAARA, Enontekiö}

\section{Pollen concentrations}

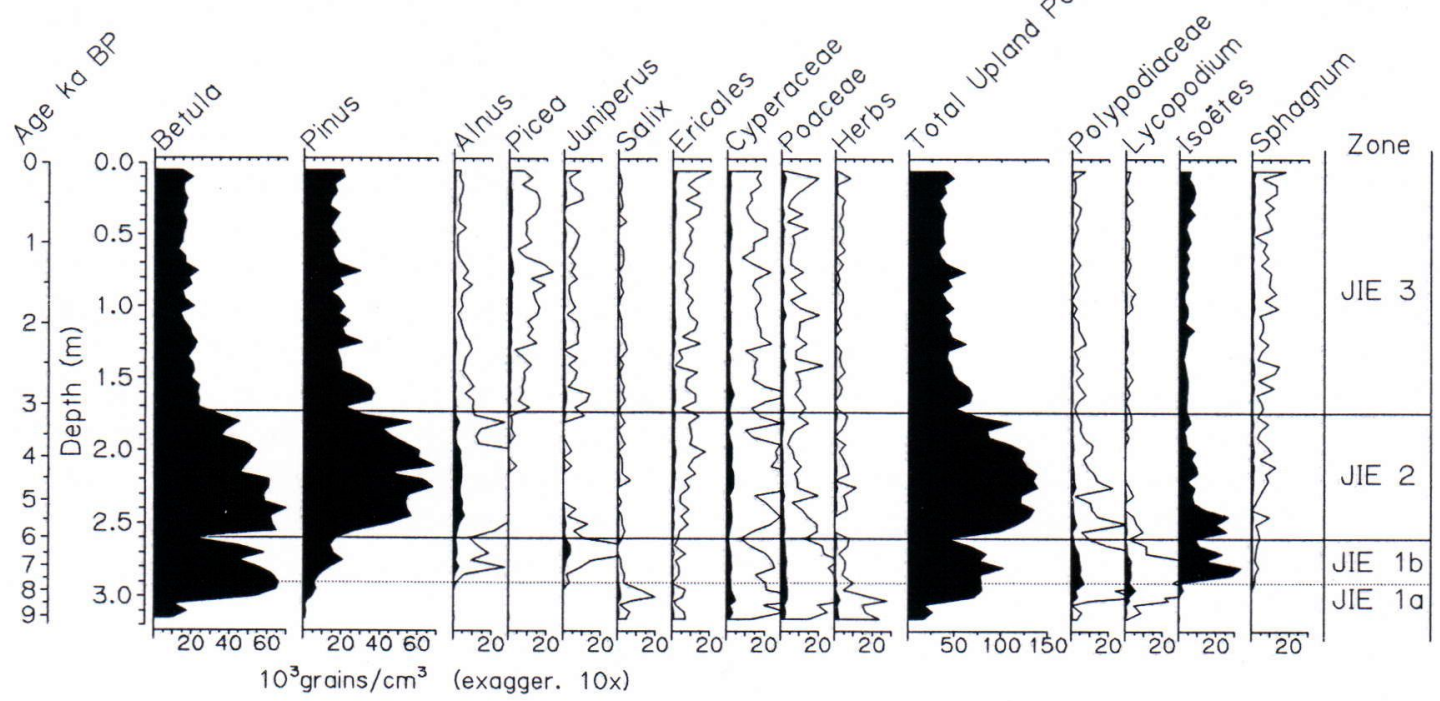

Fig. 5. Pollen concentration diagram of Jierstivaara.

that the basal part of the Isohattu sequence is sligthly truncated compared with Jierstivaara.

IH 2 ( ca. 6000-3000 BP). The zone corresponds to the pine-alder stage in the regional pollen stratigraphy. In the beginning of the zone Ericales becomes more abundant and Sphagnum starts to occur regularly. Some spruce pollen is sporadically present almost throughout. The end of the zone is marked by the beginning of a continuous spruce curve and by the regular occurrence of juniper. Pine 


\section{ISOHATTU, Enontekiö}

Pollen percentages of selected taxa

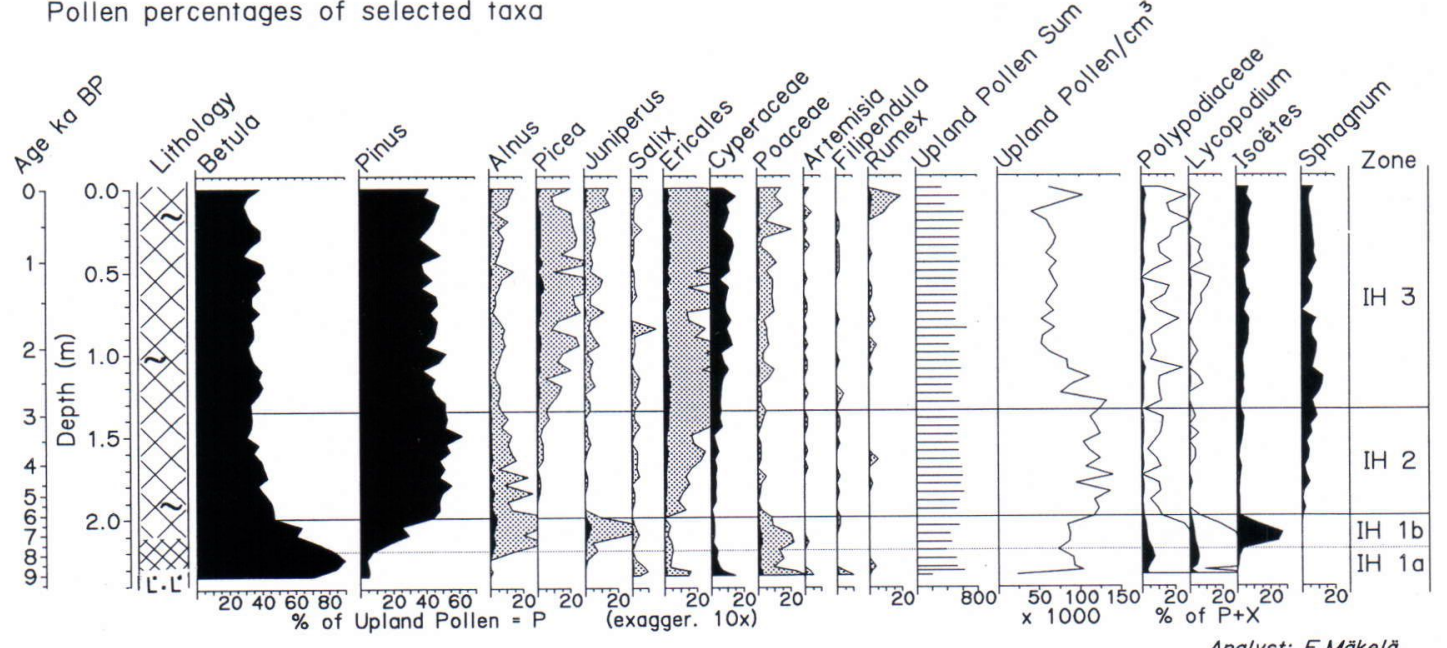

Fig. 6. Pollen percentage diagram of Isohattu. Sediment symbols as in Fig. 3.

\section{ISOHATTU, Enontekiö}

\section{Pollen concentrations}

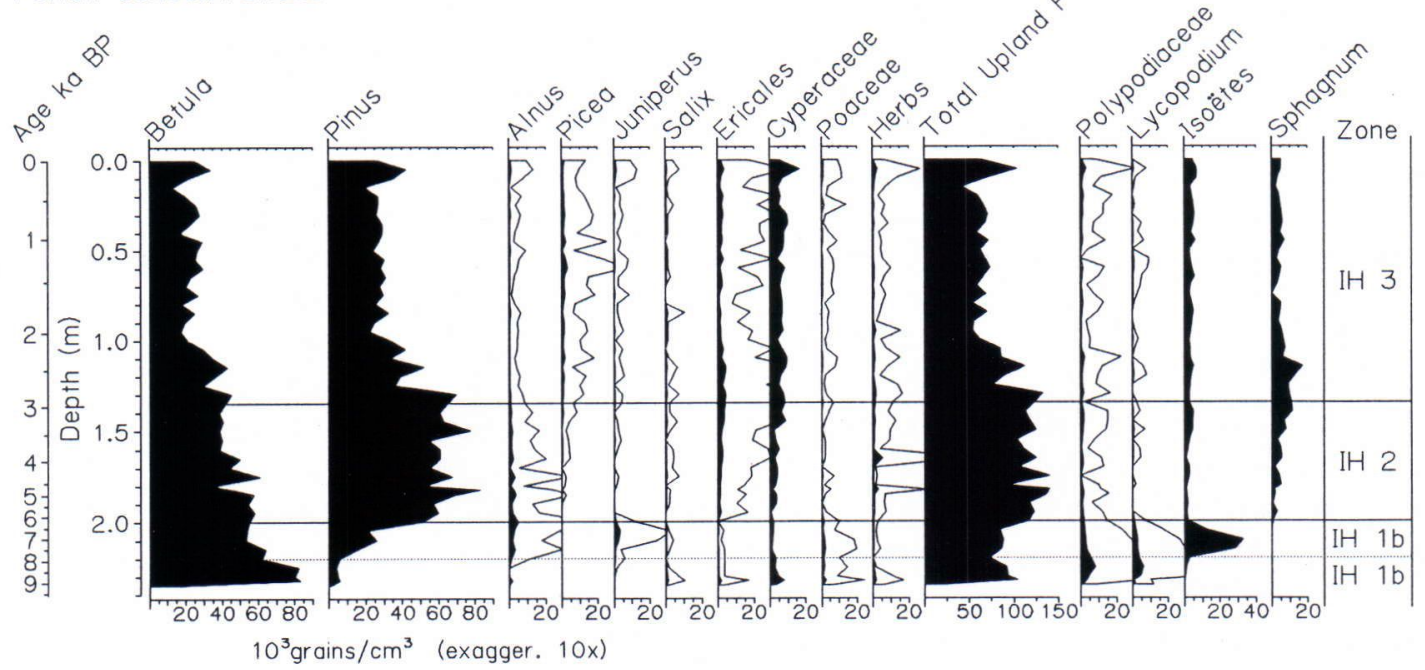

Fig. 7. Pollen concentration diagram of Isohattu.

concentrations show a sharp drop at the end of the zone, much in the same way as at Jierstivaara, but the the drop in the birch concentrations is less pronounced.

IH 3 (ca. 3000 BP-present). This zone corresponds to the pine-spruce stage. The NAP percentages and concentrations show a slightly rising trend towards present, but generally no significant changes occur.

The evolution of the forest vegetation is consistent 
with the regional vegetation history described earlier (Hyvärinen, 1978, 1993). The spread of pine turns out to be fairly late, however (see discussion below).

\section{Pollen concentrations vs. sedimentation rates}

The pollen evidence, in agreement with the radiocarbon data, indicates a period of slow rates of sedimentation before the appearance of Picea in the records. The upper half of the sediment cores is characterized by a continuous occurrence of Picea pollen although the period in question comprises only one third of the history of the lakes.

Pollen concentrations are expected to vary with varying rates of matrix accumulation, and such variations may mask or distort any changes in the amounts of pollen produced by the vegetation. Changes due to varying dilution by matrix may be eliminated by using annual pollen accumulation (pollen influx) rates, which then should give a better picture of vegetation changes. However, even the influx rates may vary spuriously if the changes in matrix accumulation are mainly due to changes in the input of allochtonous material, including pollen (e.g. Pennington, 1973; Hyvärinen, 1977). This is what seems to have happened here in both profiles (Fig. 8). Isohattu is an especially obvious case.

At Isohattu the sudden rise in the influx rates of both pine and birch in the middle of zone $\mathrm{IH} 2$, between 5000 and $4500 \mathrm{BP}$, is clearly related to the simultaneous rise in the matrix accumulation. We conclude that the input of allochthonous pollen into the basin must have greatly increased at this point. The concentrations per unit volume show little change, however, because the dilution by matrix increases at the same time.

In the Jierstivaara core the pattern is not quite as clear because the rate of matrix accumulation rises more gradually, and the first rise coincides with the zone boundary JIE $1 / 2$, hence with a major change in the vegetation. However, similarly as in the case of Isohattu, the simultaneous rise in the influx values of both pine and birch together with the change in the matrix accumulation rate suggests an increase in the allochthonous pollen contribution. The sharp, temporary decline in the pollen concentration and influx values around 6000 B.P. is discussed further below.

It appears then that the pollen influx rates obtained for the upper part of the cores with a rapid matrix accumulation are significantly raised by an increased input of allochthonous material, and they are not comparable with the values in the lower part of the cores. Earlier studies of pollen deposition rates in Lapland have suggested that the pine pollen influx varies from less than 500 grains $/ \mathrm{cm}^{2} /$ year for sites outside the range of pine to 1500 - 2000 grains for sites in continuous pine forest (Hyvärinen, 1975, 1976). These estimates are derived from sediments with moderate and even rates of matrix accumulation, and they agree very closely with the results subsequently obtained from pollen traps (Hicks, in print). The core-top values for pine at the present sites, with little or no local pine, are between 1000 and 1500, hence more than twice as high as would be expected. The values in the lower part of zone IH 2, before the marked acceleration of the matrix accumulation, may be more realistic as indices of vegetation densities, and they would be consistent with sparse pine woods growing locally.

On the basis of diatom and cladoceran analyses from the Jierstivaara and Isohattu cores, Hyvärinen \& Alhonen (1994) concluded that the changes in sedimentation are associated with water level changes in the basins. According to them, a dry stage with low lake levels would have occurred in early to mid-Holocene times, the dryness culminating between 6000 and 5000 BP. After that increasing effective humidity caused the lakes to rise to their present level. The lakes are concidered to have maintained their present water levels during the last 3000 years.

The rise of the lake levels after the dry episode coincides with the maximum pollen deposition rates in the cores. The rising water level and intensified surface runoff may have eroded pollen-rich material from the lake shores. The temporary fall in the concentrations in the 


\section{JIERSTIVAARA A. Concentrations B. Influx rates}

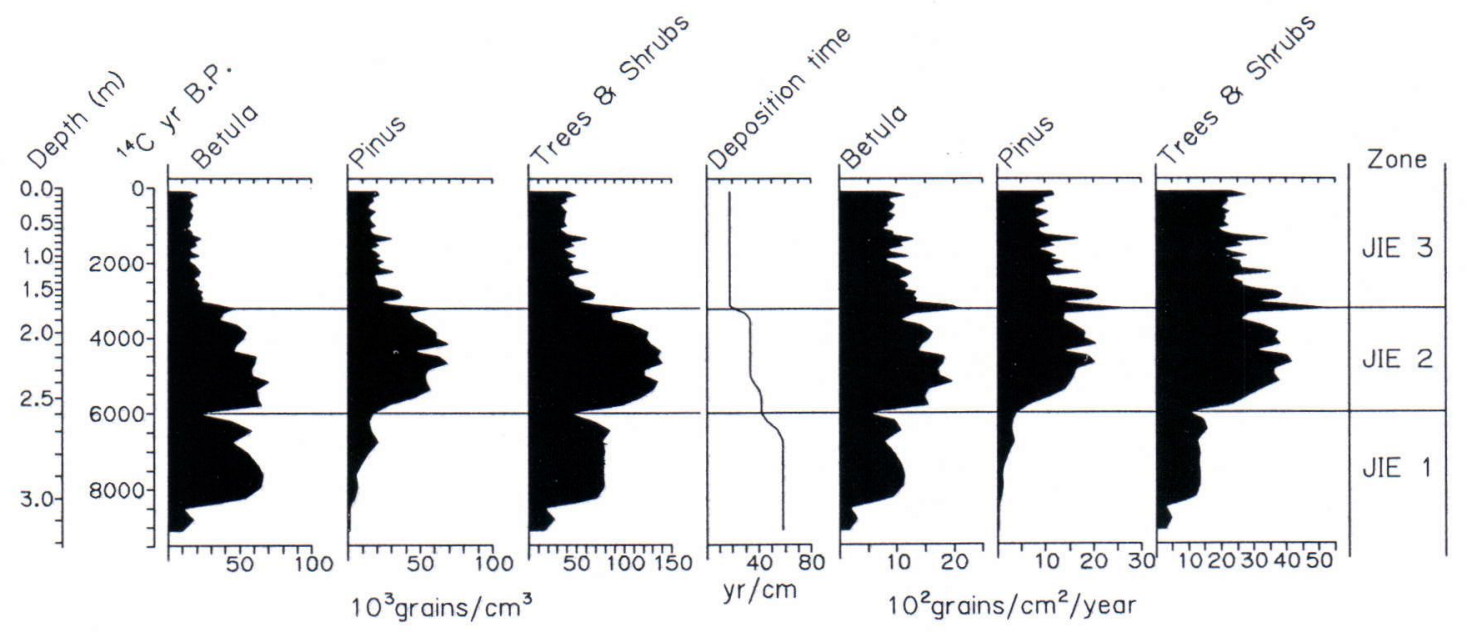

ISOHATTU A. Concentrations B. Influx rates

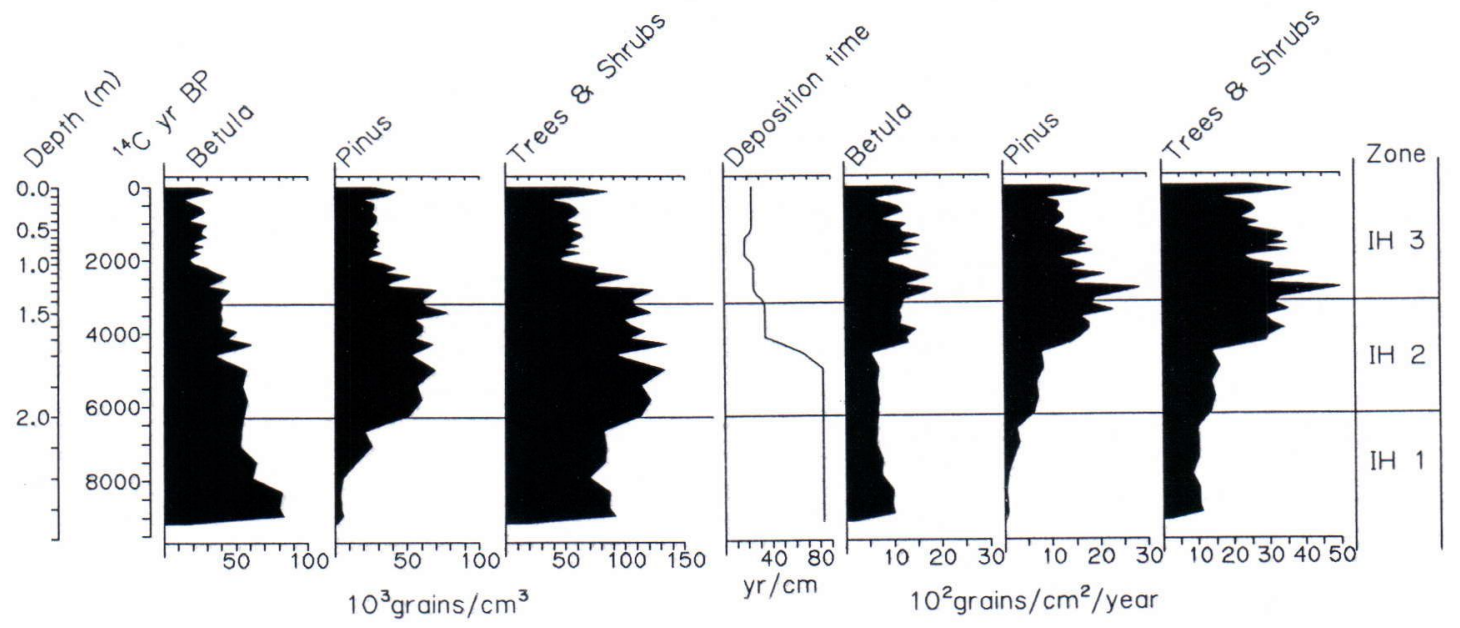

Fig. 8. Comparison of pollen concentrations and influx values in the cores of Jierstivaara and Isohattu. Note vertical scale in radiocarbon years.

Jierstivaara diagram may imply a stagnant interval with a shallow water table and decreased runoff from the basin margins. On the other hand, changes in the vegetation and in the local pollen production were also involved. The arrival of pine and the establishment of mixed birch-pine forests will naturally have contributed to the rise in the pine pollen concentrations in zone 2 .

\section{FOREST HISTORY}

The arrival of pine in the Pöyrisjärvi area is difficult to determine exactly by means of the pollen 
evidence. The complex deposition pattern with allochtonous pollen material masks the real concentrations in the vital section. The pollen influxes were not used in the interpretation of the results because of the uneven rates of sediment growth.

We assume that the declining trend in birch concentrations towards the end of zones JIE1 and $\mathrm{IH} 1$, associated with the rising pine values, indicates the arrival of pine around $6000-6500 \mathrm{BP}$. This interpretation is supported by the contemporaneous drop in Juniperus. In the present mountain birch region juniper is often a prominent component in the understory. A short Betula-Juniperus phase preceding the arrival of pine is a common feature in the pollen diagrams of northern Lapland (Eronen \& Hyvärinen, 1982; Hyvärinen, 1985, 1993). The light demanding juniper is probably shaded out with the establishment of mixed birch-pine forest, and its abundant occurence is thus a transient phase in the forest succession.

After the arrival of pine 6000-6500 BP its rising pollen concentrations do not seem to affect the birch concentrations very much, that is, birch does not seem be replaced, and we believe that pure pine forest never spread to the area. Pine trees may even have been absent in the immediate vicinity of Jierstivaara basin. Instead, the lower site of Isohattu was probably surrounded by mixed forests where birch was accompanied by pine.

The suggested arrival of pine seems fairly late in comparison with earlier results from other parts of Lapland. According to Hyvärinen (1975, 1976, 1985) and Eronen \& Hyvärinen (1982) the spread of pine in northern Fennoscandia occurred between 8500-7000 BP. The oldest dates for subfossil pine logs collected from the present area are in the neighbourhood of 6000 BP (P. Zetterberg, oral information 1993), hence consistent with the pollen evidence. However, the pine curves show long tails and moderately high concentration values preceding the final rise, which points to the presence of pine at stations not far away well before its local invasion.

The retreat of pine and birch is also difficult to follow in detail. In earlier pollen records the retreat of pine is usually seen to start well before the arrival of spruce to its northern limits (e.g. Hyvärinen 1975, 1993). In the present diagrams the most substantial change, both in terms of percentage composition (reappearence of juniper) and pollen concentrations, coincides closely with the beginning of the continuous spruce curve. However, at Jierstivaara the declining trens in both pine and birch concentrations start somewhat earlier, during the latter half of zone JIE 2. At Isohattu the drop in pine concentrations is more abrupt, and the drop in birch seems to be a slightly later event. But as the changes in the concentration trends may in part depend on local changes in sedimentation, detailed comparisons are hardly justified. We cannot therefore offer any accurate estimate about the onset of the tree-line retreat in the present area. One has to do with the obvious remark that the contemporary situation has prevailed during the last 2000 years at least, during which time the concentrations do not change significantly and the rate of sedimentation appears to have been constant.

\section{DISCUSSION OF THE CLOSE-INTERVAL DIAGRAMS}

The close-interval analysis yielded 80 samples between 220 and $300 \mathrm{~cm}$. Calculated on the basis of the deposition rates each sample represents from about $60 \mathrm{yr}$ in the lowermost part of the section $(300-275 \mathrm{~cm})$ to about 40-30 $\mathrm{yr}$ in the upper part $(275-220 \mathrm{~cm})$.

The pollen percentages (Fig. 9) show in more detail the same trends as the long diagram (Fig. 4), namely a steady decrease in Betula and an increase in Pinus. The increasing trend of Pinus is interrupted by a decline in $262-252 \mathrm{~cm}$ which is followed by even higher Pinus pollen values than before. In the long diagram (Fig. 4) the Juniperus maximum ends at the JIE $1 \mathrm{~b} / \mathrm{JIE} 2$ transition, but here it extends up to $255 \mathrm{~cm}$ where Pinus rises.

Fig. 10 shows the short decline in pollen concentrations of Fig. 5 at a larger scale. The lower part of the diagram, namely zones JIE $1 \mathrm{a}$ and JIE $1 \mathrm{~b}$ 


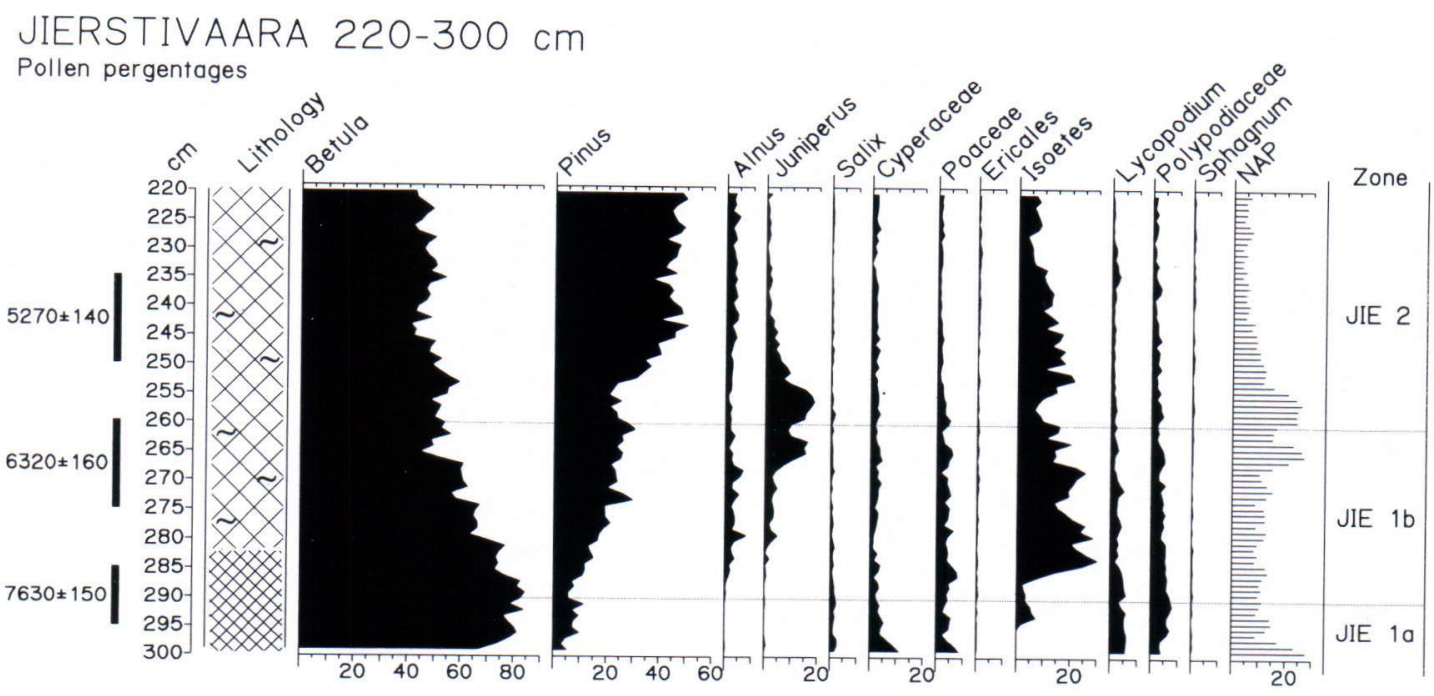

Fig. 9. Close-interval pollen percentage diagram for the $220-300 \mathrm{~cm}$ section of the main core of Jierstivaara (cf. Fig. 4).

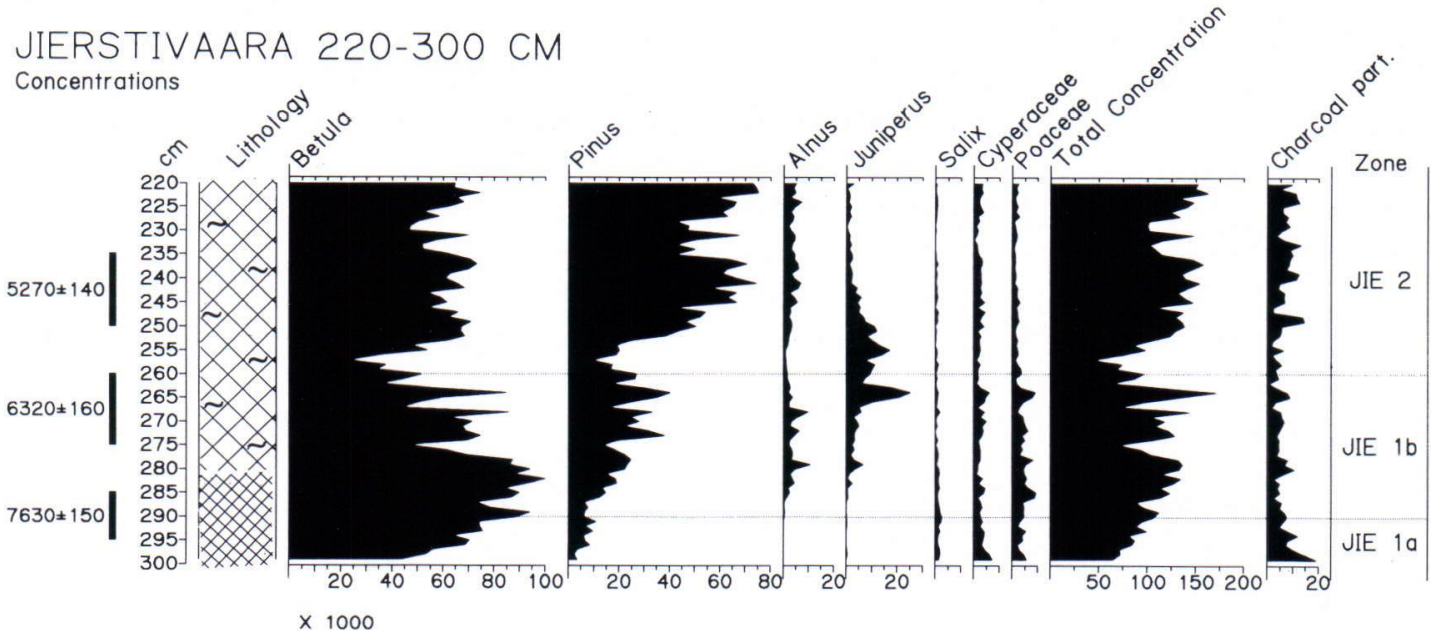

Fig. 10. Close-interval pollen concentration diagram for the $220-300 \mathrm{~cm}$ section of the main core of Jierstivaara (cf. Fig. 5).

are characterized by first high and then gradually declining values of Betula and increasing values of Pinus. Between 265 and $250 \mathrm{~cm}$ there is a marked decrease in the concentrations of all taxa. However, the curve of Juniperus recovers earlier, and its second peak partly coincides with the overall concentration minimum. Above $265 \mathrm{~cm}$ the concentrations rise again markedly, especially those of Pinus, which remain at the same level as the Betula values for the upper part of the diagram. Charcoal particles are constantly scarce throughout the diagram.

The section studied with close-interval analyses shows the development of vegetation from about 
8200 to $4500 \mathrm{BP}$. The phase of minimum concentration values $(265-250 \mathrm{~cm})$ coincides with the time of the lowest water level in the lake (Fig. 7 in Hyvärinen \& Alhonen 1994). It covers a period of about 600 radiocarbon years, from c. 6200 to $5600 \mathrm{BP}$.

Most probably the main reason to the temporary decline in pollen concentrations was an exceptionally low input of allochthonous material to the basin under conditions of maximal dryness, when the lake level was low, the shores stable and the surface runoff minimal. When the humidity increased and the water level rose, erosion and redeposition intensified, and a substantial rise in pollen concentrations resulted.

In might be argued that not all features in the pollen stratigraphy are satisfactorily explained by changes in sedimentation and matrix origin. An alternative, or additional explanation would be a temporary reversal in the vegetational development. Judging by the declining trend in Betula concentrations in zone JIE $1 \mathrm{~b}$ at the same time as Pinus concentrations are rising, the spread of Pinus in the area started prior to the concentration minimum. A halt in the spread of Pinus would then

\section{REFERENCES}

Enell, M. \& Larsson, P. 1985. Vatten och sedimentkemiska analysmetoder. Institute of Limnology, University of Lund.

Eronen, M. \& Hyvärinen, H. 1982. Subfossil pine dates and pollen diagrams from northern Fennoscandia. Geologiska Föreningens i Stockholm Förhandlingar 103, 437-445.

Faegri, K. \& IversenJ. 1989. Textbook of Pollen Analysis. John Wiley \& Sons Ltd. IV Edition. 328 pp.

Filion, L., Saint-Laurent, D., Desponts, M. \& Payette, S. 1991. The late Holocene record of aeolian and fire have followed and perhaps a decrease of Pinus in favour of light Betula-Juniperus woods. This interpretation would be suggested especially by the percentage trends showing a decline in Pinus and a reciprocal rise in Betula and Juniperus between 250 and $260 \mathrm{~cm}$. However, if real, this kind of vegetational reversal can hardly be a purely local event, and corresponding changes should then be detectable also in other pollen records from the tree-line region. No such fluctuations have been reported, but, on the other hand, no high-resolution records have been available either.

The charcoal values are exceptionally low and do not rise even during the driest period when more forest fires would be expected. The amount of charcoal rather suggests that there were no major fires in the catchment area of the lake during the whole period investigated by close-interval sampling. The charcoal values are also low in the Isohattu sequence. It seems that in our area the role of fire may not have been as important as, for example, in the north boreal forest and the forest tundra zones in Canada (Payette \& Gagnon 1985, Filion et al. 1991). activity in northern Québec, Canada. The Holocene 1, 201-208.

Hicks, S. (In print). Present and past pollen records of Lapland forests. Review of Palaeobotany \& Palynology.

Hyvärinen, H. 1973. The deglaciation history of eastern Fennoscandia - recent data from Finland. Boreas 2, 85-102.

Hyvärinen, H. 1975. Absolute and relative pollen diagrams from northernmost Fennoscandia. Fennia 142. Helsinki.

Hyvärinen, H. 1976. Flandrian pollen deposition rates and tree-line history in northern Fennoscandia. Boreas 


\section{$5,163-175$.}

Hyvärinen, H. 1978. Pohjois-Lapin kasvillisuuden kehitys jääkauden jälkeen. Acta Lapponica Fenniae 10, 7-17.

Hyvärinen, H. 1985. Holocene history of the Alta area, an isolated pine forest north of the general pine forest region in Fennoscandia. Ecologia Mediterranea 11, 69-71.

Hyvärinen, H. 1993. Holocene pine and birch limits near Kilpisjärvi, western Finnish Lapland: pollen stratigrafical evidence. In: Frenzel, B. (ed.) Oscillations of the Alpine and Polar tree Limits in the Holocene, 19-27. Gustav Fischer Verlag, Stuttgart.

Hyvärinen, H. \& Alhonen P. 1994. Holocene lake level changes in the Fennoscandian tree-line region, western Finnish Lapland: diatom and cladoceran evidence. The Holocene 4, 251-258.
Kujansuu, $R$. 1967. On the deglaciation of western Finnish Lapland. Bulletin de la commission géologique de Finlande N:o 232.

Payette, S. \& Gagnon, R. 1985. Late Holocene deforestation and tree regeneration in the forest-tundra of Québec. Nature 313, 570-572.

Pennington, W. 1973: Absolute pollen frequencies in the sediments of lakes of different morphometry. In: Birks, H.J.B. \& West, R.G. (eds.), Quaternary Plant Ecology, 79-104. Blackwell Scientific Publications, Oxford.

Sarmaja-Korjonen, K. 1992. Fine-interval pollen and charcoal analyses as tracers of early clearance periods in S Finland. Acta Botanica Fennica 146, 1-75.

Stockmarr, J. 1971. Tablets with spores used in absolute pollen analysis. Pollen et Spores 13, 615-621. 